\title{
Linguo-imagology as a New Integrating Direction of Linguistics
}

\section{Ivanova Lyudmila Petrovna ${ }^{1}$}

Professor of National Pedagogical Dragomanov University, Kiev, Ukraine.

(date of receiving: March, 2018; date of acceptance: November, 2018)

\begin{abstract}
Linguo-imagology is considered as a new stage in the development of the language, synthesizing ideas, phenomena and methods of other directions. Linguistic and linguisticology was formed on the basis of imagology - the direction of comparative literary studies, studying the image, (hence the term) of one people or country in the eyes of another, Since the creation of an image is achieved through the use of linguistic means, the foundations of linguo-imagology, which studies the linguistic means of creating the image of one country in the reception of another people. Mirroriness is not obligatory. Thus, in our direction, imagology is synthesized by comparative-historical linguistics (the image of the country can vary over the centuries). axiology (the reception of the other can not be 'passive', there is always an appraisal component), linguoculturology (primarily in terms of units analysis), cognitive linguistics (the category of the linguistic personality, the linguistic picture of the world, concepts), the theory of communication in the aspect of the intercultural field., since linguistic imaging creates a solid foundation her, practical stylistics. All these provisions are implemented on the basis of the vision and assessment of France and the French by D.I. Fonvizin and the US Alexander Pushkin.
\end{abstract}

Keywords: Linguo-imagology, Linguoculturology, Intercultural Communication, A.S. Pushkin, D.I. Fonvizin.

1. E-mail: lupiv1303@gmail.com 


\title{
Лингвоимагология как новое интегрирующее направление языкознания
}

\section{Иванова Людмила Петровна ${ }^{1}$}

Профессор Национального педагогического университета

\author{
м. М.П. Драгоманова, \\ Киев, Украина.
}

(дата получения: март 2018 г.; дата принятия: ноябрь 2018 г.)

\begin{abstract}
Аннотация
В статье лингвоимагология рассматриваетея как новый этап в развитии языкознания, синтезирующий идеи, феномены и методы других направлений. Лингвоимагология сформировалась на базе имагологии - направления сравнительного литературоведения, изучающего образ, имидж (отсюда термин) одного народа или страны в глазах другого, как правило, анализ зеркальный. Поскольку создание образа достигается за счет использования языковых средств, создались основы лингвоимагологии, изучающей языковые средства создания образа одной страны в рецепщии другого народа. Зеркальность необязательна. Таким образом, в нашем направлении синтезируются имагология, сравнительноисторическое языкознание (образ страны на протяжении веков может меняться), аксиология (рецепция другого не может быть 'пассивной', всегда присутствует оценочный компонент), лингвокультурология (прежде всего в аспекте единиц анализа), когнитивная лингвистика (категория языковой личности, языковой картины мира, концепты), теория коммуникации в аспекте межкультурной коммуникации, поскольку лингвоимагология создает прочный фундамент последней, практической стилистики. Все указанные положения реализуются на материале видения и оценки Франции и французов Д.И. Фонвизиньм и США А.С. Пушкиным.
\end{abstract}

Ключевые слова: Лингвоимагология, Лингвокультурология, Межкультурная Коммуникация, А.С. Пушкин, Д.И. Фонвизин.

1. E-mail: lupiv1303@gmail.com 


\section{Введение}

Лингвоимагология - новое разрабатываемое нами направление языкознания сформировалось на базе имагологии - области сравнительного литературоведения, восходящего, в свою очередь, к срвнительно-историчному языкознанию. На Украине наиболее яркие работы в области имагологии принадлежат перу Д.С. Наливайко, В.В. Орехова и др. В.В. Орехов квалифицирует имагологию как отрасль сравнительного литературоведения, изучающего литературные образы (имиджи) инонациональных государств, народов [Орехов 2008. 7], причем это изучение должно быть зеркальным. Автор подчеркивает: «Важнейшая проблема имагологии - степень участия в формировании образов стран и народов (в творчестве отдельных авторов и общелитературном контексте) трех основньх компонентов: объективных причин (исторических, политических, социальных), субъективных факторов (личных авторских впечатлений, переживаний) и традиционных представлений» (Орехов 2008. 7). Указанные факторы вербализируются, что дает основания для создания лингвистической имагологии лингвоимагологии. Зеркальные характеристики имиджей, конечно, интересны, однако далеко не всегда возможны. Так, например, мы проанализировали восприятие Африки Н.С. Гумилевым - выдающимся поэтом, страстным путешественником, носителем элитарной русской культуры (Иванова 2013). Зеркальное описание России африканскими поэтами вряд ли возможно даже в наши дни.

\section{Основная часть}

Итак, первый компонент лингвоимагологии - имагология. Важны в процессе лингвоимагологического анализа сведения из классического литературоведения, поскольку главной категорией лингвоимагологии является оценка, однако, по нашим наблюдениям, оценка характеризует не столько 
оцениваемое, сколько оценивающего. Информацию о писателях, их жизни, деятельности, творческой манере дает литературоведение.

Обратимся к лингвистике. В.М. Алпатов подчеркивает: «В истории лингвистики можно видеть две тенденции: одна из них стремится изучать язык объективно и точно по образцу естественных наук, другая связана с изучением языка вместе с говорящем на нем человеком, с учетом интуиции и интроспекции. Первая тенденция господствовала в эпоху структурной лингвистики, вторая стала распространенной в наше время» (Алпатов 2015. 7). Автор, трактуя тенденции развития лингвистики, обращается к традиционному образу спирали (Там же. 10).

Лингвоимагология - это развитие идей В. фон Гумбольдта: «... подход, связываемый с именем В. фон Гумбольдта, стремится к расширению любых рамок, междисциплинарным исследованиям, постановке глобальных задач, при этом часто без сколько-нибудь строгого метода. В какой-то мере можно считать, что он увеличивает хаос. Наше время - скорее движение в такую сторону» (Там же. 18).

Итак, лингвоимагология призвана синтезировать разные направления современной лингвистики. Как уже отмечалось, через имагологию лингвоимагология связана с классическим сравнительно-историческим языкознанием.

Следующее лингвистическое направление - лингвокультурология. В свою очередь, само название свидетельствует о синтезе лингвистики и культурологии. В.А. Маслова подчеркивает: «Отношения между языком и культурой могут рассматриваться как отношения части и целого. Язык может быть воспринят как компонент культуры и как орудие культуры (что не одно и то же). Однако язык в то же время автономен по отношению к культуре в целом и может рассматриваться как независимая автономная семиотическая система, т. е. отдельно от культуры, что делается в традиционной 
лингвистике» (Маслова 2008. 132). Таким образом, и язык, и культура формируются в ментальном опыте людей, принадлежащих к одному культурно-языковому сообществу. Восприятие и оценка стран и народов порождение ментальности, культуры, языка представителя того или иного этноса.

Следующая точка соприкосновения лингвоимгологии и лингвокультурологии - предмет изучения. В. А. Маслова называет следующее: «1) безэквивалентная лексика и лакуны, . . ; 2) мифологизированные языковые единицы: архетипы и мифологемы, обряды и поверья, ритуалы и обычаи, закрепленные в языке; 3) паремиологический фонд языка; 4) эталоны, стереотипы, символы; 5) метафоры и образы языка; 6) стилистический уклад языков; 7) речевое поведение; 8) область речевого этикета» (Маслова 2001. 36 47). Все указанные единицы и категории важны и для лингвоимагологического анализа, однако в нем на передний план выходит оценка, поскольку без нее процесс познания и формирования имиджа невозможен. Таким образом, следующая наука, с которой связана лингвоимагология, - аксиология.

Лингвокультурология оперирует, прежде всего, единицами коллективного сознания - концептами, фразеологизмами, мифами и т. п. В лингвоимаголии вся информация извлекается в ходе анализа индивидуальной речи разньх жанров - путевые заметки, дневники, записки, эпистолярий, хотя возможны и художественные тексты, и публицистика (Иванова 2001).

Может возникнуть вопрос: какому материалу, каким авторам можно доверять? Наши наблюдения показывают, что подобно тому, как формируется норма языка, в становлении образа другого народа и страны целесообразно опираться на образы, наблюдения, запечатленные в языковом сознании наиболее авторитетных представителей нации, которых можно рассматривать как эталоны. Относительно последних В.М. Солнцев отмечает: «Какой-либо конкретный предмет из некоторого множества предметов, составляющих один 
класс, по тем или иным причинам может быть признан эталоном [выд. B.M. Солнцевым], или образом, но остается всего лишь вариантом среди других вариантов» (Солнцев 1971. 214).

Таким образом, и лингвокуьлтурология, и лингвоимагология изучают, прежде всего, образы в мировосприятиии того или иного народа. И если лингвокультурологическое исследование направлено на познание «себя», то лингвоимагологическое - на познание «другого», поэтому материалом для лингвокультурологии являются паремии и фразеологизмы, сгустки народной мудрости, в лингвоимагологии изучаются индивидуальные личностные оценки и другие феномены, содержащиеся в эпистолярной, мемуарной, художественной и публицистической литературе, рассматриваемые как варианты инварианта - образа того или иного народа и страны в сознании другого народа.

Следующее направление языкознания, тесно связанное с лингвоимагологией, - теория коммуникации, особенно важнейшая ее составляющая - межкультурная коммуникация. По нашему глубокому убеждению, последняя должна опираться на данные лингвоимагологии (Иванова 2014). Аргументируем свою позицию.

В.А. Маслова подчеркивает, что «задачами межкультурной коммуникации становится определение «зон напряжения» при межкультурных контактах, предотвращение коммуникативных неудач» (Маслова 2008. 83). Таким образом, межкультурная коммуникация носит в основном прикладной характер: как общаться, не обидев собеседника - носителя иной культуры, как коммуникантам избегать культурного шока. Лингвоимагология создает прочный историко-теоретический фундамент межкультурной коммуникации, поскольку последняя описывает общение здесь и сейчас, однако национальные традиции, правила внутри- и межнационального общения складывались постепенно, иногда кардинально менялись на протяжении веков. Примером 
может служить отношение к Германии и немцам в XVIII в., в Петровскую эпоху, в период Первой и Великой Отечественной войны, в наши дни. То же можно сказать об армяно-турецких и армяно-азербайджанских взаимоотношениях

Наши соотечественники начали описывать свои путевые впечатления с незапамятных времен, первым или одним из первых было «Хожение за три моря» Афанасия Никитина, статейные списки Г.И. Микулина (Англия, 1600 г.), Федота Елчина (Грузия, 1639-1640 гг.) и многие другие

Путешествия, предпринятые для ознакомления с жизнью других стран и народов, целенаправленно осуществлялись с XVII века, когда наши соотечественники направлялись прежде всего в Европу.

Обратимся к письму-напутствию сыну сподвижницы Екатерины II Президента Российской Академии Наук Е.Р. Дашковой, не утратившему своего значения и по сей день: «У путешественника должны быть постоянно открыты и глаза и уши; потому что сцена изменилась и размышление, вызванное ею, исчезает вместе с ней. Предметы твоего наблюдения так разнообразны и многочисленны, что я укажу тебе только некоторые главные [выд. нами - Л.И.]. Сюда относятся свойство и форма правления, законы, нравы, влияние, народонаселение, торговля; географические и климатические условия, иностранная и внутренняя политика, произведения, религия, обычаи, источники богатства, действительные и мнимые средства общественного кредита, подати, пошлины и различные условия различных сословий. Эти исследования достойны внимания философа, и ни один путешественник не должен пренебрегать ими, если только он не хочет остаться тупым и бессмысленным зрителем всех этих явлений, не способным ни к умственному, ни нравственному совершенству» (Дашкова 1960. 341-342). С горечью сравним цели и задачи путешественников - наших современников, особенно любителей пляжного отдыха. 
Мы адаптировали написание к современным техническим возможностям, однако подчеркнем своевременность и актуальность не только содержания, но и формы изложения - образца книжного публицистического стиля. Думается, историку стилистики следует обратить внимание на писания кн. Е. Р. Дашковой как на первые образцы русского эпистолярного и публицистического стиля.

Е. Р. Дашкова подчеркивает необходимость деятельностного восприятия чужих стран и народов: «... сравнивая иностранную жизнь с жизнью своего Отечества, стараясь исправить, что найдешь в нем дурного, учреждая, что сочтешь полезным его благосостоянию, ты будешь другом и благодетелем своей страны» (Дашкова 1960. 344).

Уже в XVIII в. русские путешественники осознавали необходимость уважительного отношения к другим народам (то, что мы сейчас называем толерантностью), прежде всего это касается религии, так, Е.Р. Дашкова пишет сыну: «Относительно религиозных мнений, где бы ты ни соприкасался с ними, должен уважать их. Серьезное или шуточное опровержение их, каковы бы они ни были, оставляет по себе самое горькое и оскорбительное впечатление на человеке и никогда не забывается» (Там же.). Для сравнения вспомним карикатуры на пророка Мухаммеда во французских журналах XXI века и повлекшиеся за ними последствия.

Обратим внимание на следующее: очень важно оставить после себя хорошее впечатление, поскольку оно касается не только конкретного путешественника, но и распостраняется на весь народ и страну, которым путешественник принадлежит.

И еще одно своевременное предостережение: «... непростительно грубо и несправедливо судить об одном народе по мерке другого» (Там же.). Отметим утверждение С.Г. Тер-Минасовой о том, что родная культура обычно воспринимается как единственно правильная. 
Таким образом, теория коммуникации должна опираться на прочный фундамент лингвоимагологии, поскольку последняя дает информацию о том, как изменяется общение во времени, какие факторы влияют на указанные процессы, в частности, роль факторов адресата и адресанта. В процессе межкультурной коммуникации необходимо учитывать сложившиеся традиции общения и процесс их формирорвания, о чем дает информацию лингвоимагология.

Подводя итоги, подчеркнем взаимосвязь лингвоимагологии со сравнительно-историческим языкознанием, аксиологией, лингвокультурологией, теорий коммуникации.

В качестве примера указанного синтеза рассмотрим фрагмент из путевых заметок и писем Д.И. Фонвизина, посвященных Франции и французам. Еще до приезда во Францию у Д.И. Фонвизина сложились определенные представления и соответствующие ожидания. Возможно, поэтому разочарование было особенно «жестоким»: «Я думал сперва, что Франция, по рассказам, земной рай, но ошибся жестоко. Все люди, и славны бубны за горами. Удивиться должно ... какие здесь невежды. Дворянство, особливо, ни уха ни рыла не знает. Многие в первый раз слышат, что есть на свете Россия и что мы говорим в России языком особенным, нежели они. Человеческое воображение постигнуть не может, как при таком множестве способов к просвещению здешняя земля полнехонька невеждами» (Фонвизин 1959. 423). Как обычно (и это вполне естественно) автор смотрит на мир сквозь призму реалий России, где столичные дворяне были людьми образованными, хотя невежество поместного высмеяно им в бессмертной комедии «Недоросль», а Митрофанушка стал нарицательным. Русские дворяне, как правило, владели французским языком, французские же не представляли существование русского языка, отличного от французского. Возмущение Д.И. Фонвизина проявляется, в частности, в том, что в небольшом микротексте используются 
два фразеологизма - элементы самого национального пласта языка: «славны бубны за горами», «ни уха ни рыла не знает».

Русского путешественника удивляет и возмущает «ротозейство» французов (вспомним, что А.С. Пушкин главной особенностью русского мужика считает отсутствие ротозейства (Пушкин 1962. 395-396)): «... народ здешний с природы весьма скотиноват. Я думаю, что таких ротозей мало водится. По всем улицам найдешь кучу людей, а в средине шарлатана, который выкидывает какие-нибудь штуки, продает чудные лекарства и смешит дураков шутками. Часто найдешь на площадях людей около бабы или мужика, которые, поставя на землю род шкапа с растворенными дверцами, кажут в шкапу куколок. Баба во все горло поет духовные стихи, а мужчина играет на скрипке; словом, народ праздный и зазевывается охотно, а притом и весьма грубый. Лакеи здешние такие неучи, что в самых лучших домах, быв впущены в переднюю, кто бы ни прошел мимо, дама или мужчина, ниже с места тронуться и, сидя, не снимают шляп) (Фонвизин 1959. 428-429).

Безделье и праздность Д.И. Фонвизин резко осуждает («народ с природы скотиноват», «праздный», «ротозеи», «дураки», «народ праздный и грубый»). Не одобряет русский путешественник, используя вульгаризмы, скоморохов (шарлатаны, выкидывают штуки, смешат дураков) и бродячий кукольный театр (баба ... поет во все горло).

Особая категория французских женщин - «девки»: «Теперь поговорю о другой приманке, а именно: о девках. Здесь все живут не весьма целомудренно; но есть состояние особенное, называющееся lesfilles, то есть: непотребные девки, осыпанные с ног до головы бриллиантами. Одеты прелестно; экипажи такие, каких великолепнее быть не может. Дома, сады, стол - словом, сей род состояния изобилует всеми благами света сего. Спектакли все блистают от алмазов, украшающих сих тварей. Они сидят в ложах с своими любовниками, из коих знатнейшие особы имеют слабость срамить себя публично, садясь с ними в ложах. Богатство их неисчислимо; а 
потому благородные дамы взяли другой образ нарядов, т. е. ни на одной благородной не увидишь бриллиантика. Дорогие камни стали вывескою непотребства» (Фонвизин 1959. 446).

В данном микротексте обращает на себя внимание ряд моментов. Вопервых, отсутствие в тот период именования «девок» - автор не назвал их ни куртизанками (вспомним роман О. де Бальзака «Блеск и нищета куртизанок»), ни женщинами легкого поведения, ни проститутками. Данный феномен однозначно осуждается ('непотребные девки', 'непотребство', 'твари'). Фрагмент построен на контрасте: с одной стороны, великолепие ('экипажи такие, каких великолепнее быть не может', 'сей род состояния изобилует всеми благами света сего', 'богатство их неисчислимо'), с другой стороны, общение с ними резко осуждается ('знатнейшие особы имеют слабость срамить себя публично, садясь с ними в ложах'). Хотя, как следует из контекста, любовники 'девок' ничего не стыдятся и выставляют отношения напоказ. С третьей стороны, форма протеста 'благоройных дам': отсутствие 'бриллиантика'. Происходит символизация: «Дорогие камни стали вывескою непотребства». Отметим, что и современные француженки не питают страсти к драгоценным камням.

Приводимые примеры касаются обычаев, традиций, культуры Франции. Д.И. Фонвизин предстает внимательным путешественником, патриотом, государственным деятелем, ученым, стремящимся обнаружить причину и следствие описываемых явлений и фактов, особенно негативных.

Д.И.Фонвизин путешествовал по Франции , жил в различных городах, имея возможность видеть жизнь страны и народа как бы “изнутри”.

Иначе складывались обстоятельства у великого А.С. Пушкина.В силу известных политических причин он не мог покидать пределы России.Один только раз вместе с русскими войсками он дошел до турецкого Эрзрума и с ними же вскоре возвратился обратно.Тем не менее высочайшая образованость, 
эрудиция, природная гениальность позволили ему сделать ценнейшае в лингвоимагологическом наблюдении.

С одной стороны, в его сознании обьединялись самые различные процессы , происходящие в мире, с другой - он четко и прозорливо характеризовал отдельные страны.

Примером первого может служить видение истоков и путей развития литератур Европы: “Два обстоятельства имели решительное действие на дух европейской поэзии: нашествие мавров и крестовые походы" (Пушкин 1962. 256)

Далее следует конкретизация этого воздействия: "Мавры внушили ей исступление и нежность любви, приверженность к чудесному и роскошное красноречие востока; рыцари сообщили свою набожность и простодушие, свои понятия о геройстве и вольность нравов походных станов Годфреда и Ричарда" (Там же.) Обратим внимание на высокою оценку мавританских реалий: 'исступление и нежность любви', 'роскошное красноречие'. Отметим, что подобную почти восторженую характеристику Востока и по сей день не часто встретишь в европейской литературе и литературоведении. Влияние рыцарства практически не оценивается (разве что “вольность нравов походных станов"), лишь констатируется.

В результате указанного воздействия в европейских литературах сложилась следующая ситуация: "Италия присвоила себе ее эпопею, полуафриканская Гишпания завладела трагедией и романом, Англия противу имени Dante, Ариосто и Кальдерона с гордостью выставила имена Спенсера, Мильтона и Шекспира. В Германии (что довольно странно) отличилась новая сатира, едкая, шутливая, коей памятником остался Ренике Фукс" (Там же.. 265)

Видение великого русского поэта виглядит весьма современно, исключение составляет Германия: для наших современников символы немецкой поэзии Гете, Шиллер, Фукс известен, прежде всего, специалистам. 
Linguo-Imagology as a New Integrating Direction of Linguistics $\mathbf{5 7}$

С рассматриваемой точки зрения очень интересно сравнение литературоведческой концепции Буало с Кораном - главным произведением, регулирующим жизнь и деятельность мусульман: “...Буало обнародовал свой Коран - и французская словесность ему покорилась" (Там же.. 266).

Вторая позиция - видение и оценка страны, где А.С.Пушкин никогда не бывал, - Соединенные Штаты Америки. Толчком к размышлению русского поэта послужили “Записки Джона Теннера": "В Нью-Йорке недавно изданы “Записки Джона Теннера", проведшего тридцать лет в пустынях Северной Америки, между дикими ее обитателями" (Там же. 166)

Негативная оценка индейцев с опорой на наблюдения Д. Теннера конкретизируется: “Легкомысленность, невоздержанность, лукавство и жестокость - главные пороки диких америкацев. Убийство между ними не почитается преступлением, но родственники и друзья убитого обыкновенно мстят за его смерть"... "Храбрость почитается между индейцами главною человеческою добродетелью: трус презираем у них наравне с ленивым или слабым охотником. Иногда, если убийство прощаемо в пьянстве или ненарочно, родственники торжественно прощают душегубца" (Там же. 177).

Обратим внимание на лейтмотив характеристики: 'дикие'. Контрастируют высокое слово 'торжественно' и просторечное 'душегубец'.

Несмотря на 'дикость' индейцев, А.С. Пушкин не видит в действиях США цивилизационной функции: “Отношения Штатов к индийским племенам, древним владельцам земли, ныне заселенной европейскими выходцами, подверглись также строгому разбору новых наблюдателей. Явная несправедливость, ябеда и бесчеловечие американского Конгресса осуждены с негодованием; так или иначе через меч и огонь, или от рома и ябеды, или средствами более нравствеными, но дикость должна исчезнуть при приближении цивилизации.Таков неизбежный закон.Остатки древних обитателей Америки скоро совершенно истребятся; и пространные степи, 
необозримые реки, на которых сетьми и стрелами добывали они себе пищу, обратятся в обработанные поля, усеянные деревнями, и в торговые гавани, где задымятся пироскафы и разовьется флаг американский” (Там же. 165-166).

Обратим внимание на то, что развитие цивилизации на индейских землях констатируется и никак не оценивается, однако несправедливость и жестокость победителей, используемые или приемы принуждения русским поэтом гневно осуждаются: 'меч', 'огонь', 'ром', 'ябеда' (во времена А.С.Пушкина это клевета, каверза) - номинации крайне уничижительные. Они должны привести к полному истреблению коренного населения.Отметим прозорливость А.С. Пушкина, хотя до полного истребления дело не дошло, проблема коренного населения в СШІА осталась.

Действие европейской цивилизации оказалось ограниченным и пагубным: "Американские индейцы вообще звероловы, цивилизация европейская, вытеснив их из наследных земель, подарила им порох и свинец: тем и ограничилось ее благодетельное влияние” (Там же. 172). Обратим внимание на инверсию ('цивилизация европейская’), актуализирующую именно цивилизацию, а не ее европейскую прикрепленность, а также атрибутив 'благодетельное', содержащий благодаря внутренней форме (благо+делать) скрытую горькую иронию автора.

Тем не менее жизнь среди индейцев существенно повлияла на мировоззрение Д.Теннера: он ..."иногда выдает себя за человека, не доступного предрассудкам; но поминутно обличает свое индийское суеверие.Теннер верит снам и предсказаниям старух: те и другие для него всегда сбываются. Когда голоден, ему снятся жирные медведи, вкусные рыбы, и через несколько времени в самом деле удается ему застрелить дикую козу или поймать осетра. В затруднительных обстоятельствах ему всегда является во сне какой-то молодой человек, который дает добрый совет или ободряет его" (Там же. 181). 
Данный отрывок характеризует и А.С. Пушкина, и Д.Теннера: русский писатель осуждает “предрассудки’ и 'суеверия’ американца , хотя именно его произведение возбудило особое внимание А.С. Пушкина к индейцам и искреннее сочувствие их судьбе. С другой стороны, Д. Теннер отождествляется в сознании русского писателя с идеологией США: "...Есть надежда, что Теннер со временем сделается настоящим уankee (Там же. 191). (Обратим внимание на английское написание данного варваризма). Сам же А.С. Пушкин делает примечание: "Прозвище, данное американцам; смысл его нам неизвестен" (Там же.).

Характеризуя США в целом, А.С.Пушкин проявляет себя как мудрый политолог, тонкий аналитик, поэтому под его размышлениями расписались бы и наши современники: "...Америка спокойно совершает свое поприще, доныне безопасная и цветущая, сильная миром, упроченным ей географическим ее положением, гордая своими учреждениями.Но несколько глубоких умов в недавнее время занялись исследованием нравов и постановлений американских, и их наблюдения возбудили снова вопросы,которые полагали давно уже решенными. Уважение к сему новому народу и к его уложению, плоду новейшего просвещения, сильно поколебалось. С изумлением увидели демократию в ее отвратительном цинизме, в ее жестоких предрассудках, в ее нестерпимом тиранстве.Все благородное, бескорыстное, все возвышающее душу человеческую - подавленное неумолимым эгоизмом и страстию к довольству (comfort); большинство, нагло притесняющее общество раб̆ство негров посреди образованности и свободы; родословные гонения в народе, не имеющем дворянства; со стороны избирателей алчность и зависть; со стороны управляющих робость и подобострастие; талант из уважения к равенству, принужденный к добровольному остракизму; богач , надевающий оборванный кафтан, дабы на улице не оскорбить надменной нищеты, им втайне втайне презираемой: такова картина Американских Штатов, недавно выставленная перед нами." (Там же. 165).' 
Микротекст четко распадается на три части, демонстрирующих логику рассуждений автора. Первая часть - констатация благополучия страны, обусловленного в определенной степени и географическим положением. Вторая часть - ‘исследования' ‘глубоких умов’. Третья часть - гневное осуждение ('отвратительный цинизм', 'жестокие предрассудки', 'нестерпимое тиранство') американского воплощения демократии, когда большинство подавляет свободу личности и меньшинства. Все 'благородное', 'бескорыстное', 'возвышающее душу' подавляется эгоизмом и страстью к комфорту (интересно, что в русском языке слово еще не прижилось, поэтому А.С. Пушкин передает его латиницей) Такая демократия сказывается и на избирателях и на управляющих, и на талантливых людях, даже на богачах. Подчеркивается 'рабство негров посреди образованности и свободы', тоесть рабство противопоставлено не только свободе (языковые антонимы), но и образованности (контекстуальные антонимы)

Еще один момент, привлекающий внимание в процессе анализа текстов А.C. Пушкина: неустоявшаяся норма написания - ‘индейцы' - ‘индийцы', что свидетельствует о новизне для русского общества и языка данных реалий.

Таким образом, размышляя над книгой Д.Теннера, А.С. Пушкин продемонстрировал глубокую эрудицию, образованность, аналитический склад ума, а главное - взгляды и мировозрение передовой части русского общества начала XIX века. Блестящая форма изложения очевидна.

\section{Заключение}

Лингвоимагология - новое разрабатываемое нами направление языкознания. Объект лингвоимагологиии - образ, имидж (отсюда термин) одного народа или страны в глазах другого народа. Всякий образ в сознании обязательно оценивается, поэтому предмет нашего направления - оценка и языковые приемы его реализации. Материал исследования - путевые заметки, дневники, эпистолярий, художественные и публицистические тексты. 
Базой для создания лингвоимагологии явился целый ряд направлений филологии: во-первых, имагология - область сравнительного литературоведения, восходящая в свою очередь, к сравнительноисторическому языкознанию. В процессе лингвоимагологического анализа важны сведения из классического литературоведения (информация о писателях, их жизни, деятельности, творческой манере), поскольку, по нашим наблюдениям, оценка характеризирует ни столько оцениваемое, сколько оценивающего. Таким образом, второе базовое направление для лингоимагологии - аксиология. Третье направление - лингвокультурология, само название свидетельствует о синтезе лингвистики и культурологи. И язык, и культура формируются в ментальном опыте людей, принадлежащих к одному культурно-языковому сообществу. Восприятие и оценка стран и народов - порождение ментальности, культуры, языка представителя того или иного этноса.

Лингвокультурология оперирует, прежде всего, единицами коллективного сознания - концептами, фразеологизмами, мифами и т.п. В лингвоимагологии вся информация извлекается в ходе анализа индивидуальной речи разных жанров - путевые заметки, дневники и др. Лингвокультурологическое исследование направлено, прежде всего, на познание «себя», лингвоимагологическое - на познание «другого». В-четвертых, межкультурная коммуникация, носящая в основном прикладной характер: как общаться, не обидев собеседника - носителя иной культуры, как коммуникантам избежать культурного шока. Лингвоимагология создает прочный историкотеоретический фундамент межкультурной коммуникации, по сколько последняя описывает общение «здесь и сейчас». Однако национальные традиции, правила внутри - и междунационального общения складывалось постепенно.

В-пятых, языковая составляющая лингвоимагологии связана со стилистикой, стилистическим анализом, и интерпретацией языковых средств. 
Формирование традиций восприятия и оценок других стран и народов в статье рассмотрено на примере эпистолярия Кн. Е.Р. Дашковой. Видение Франции и французов проанализировано на примере фрагментов из путевых заметок и писем выдающегося русского драматурга Д.И. Фонвизина. Автор путешествовал по Франции, посетил различные города, имея возможность видеть жизнь страны и народа как бы «изнутри».

В силу известных политических причин великий поэт А.С. Пушкин пределы России не покидал. Однако высочайшая образованность, эрудиция, природная гениальность позволили ему сделать ценнейшее в лингвоимагологическом смысле наблюдение. В статье исследуется, с одной стороны, описание влияния Востока, а с другой - характеристика Соедененных Штатов Америки.

Таким образом, лингвоимагологический анализ лежит на стыке имагологии, литературоведения, стилистики, аксиологии, лингвокультурологии, теории коммуникации, что расширяет возможности современного анализа и утвежрдает статус лингвоимагологии как нового самостоятельного направления языкознания.

\section{Литература}

1- Алпатов В.М. (2015). Что и как изучает языкознание // Вопросы языкознания, № 3 - с. 7-21.

2- Дашкова Е.Р. (1990) Записки княгини Е.Р. Даиковой. Репринтное воспроизведение. М.: Изд-во «Наука». $-528 \mathrm{c}$.

3- Иванова Л.П. (2013) Африка глазами Н.С. Гумилева (лингвоимагологический acneкm) // Ученые записки Таврического национального университета им. В.И. Вернадского. Т 26 (65). № 1. Филология. Социальная коммуникация. - Симферополь, - с. 471-477.

4- Иванова Л.П. (2014). Лингвоимагология как краеугольный камень теории коммуникации и практические основы межкультурной коммуникации // Коммуникативные исследования. Изд-во «Омскийо университет». № 1, с. 916. 
5- Иванова Л.П. (2016). выковая личность кн. Е. Р. Даиковой (лингвоимагологический и гендерный аспекты) //Мовна особистість: лінгвістика і лінгводидактика (текст) МОН України, Київський національний лінгвістичний університет. Черкаський національній університет iм. Б. Хмельницького. Київ - Черкаси: Вид-во Чабаненко Ю.А. с. 34-38.

6- Иванова Л.П. (2016). Жанровые основания лингвоимагологического анализа // Жанры речи. Международный научный журнал. Изд-во Саратовского университета, № 1, с. 148-155.

7- Маслова В.А. (2001). Лингвокультурология: Учеб. пособие для студентов высиих учебныхх заведений. М.: Издательсткий центр «Академия», -208 с.

8- Маслова В.А. (2008). Современные направления в лингвистике: учебное пособие для студентов въгсиих учебныт заведений / В.А. Маслова. - М.: Издательский центр «Академия», -274 с.

9- Орехов В.В. (2008). Миф о России во франиузской литературе первой половины XLX века. - Симферополь: ОАО «Симферопольская государственная типография» (СГТ), $-200 \mathrm{c}$.

10- Пушкин А.С. (1962). Собрание сочинений в 10-ти томах. Т. VI. Критика и публицистика. Гос. изд-во художественной литературы. - М., $-586 \mathrm{c}$.

11- Солнцев В.М. (1971). Язык как системно-структурное образование. - М., Главная редакция восточной литературы издательства «Наука». -294 с.

12- Фонвизин Д.И. (1959). Собрание сочинений в 2 m., Т. 2. ГИХЛ, М-Л., -742 с.

\section{Bibliography}

1- Alpatov V.M. (2015). Chto i kak izuchaet jazykoznanie // Voprosy jazykoznanija, № $3-$ s. 7-21.

2- Dashkova E.R. (1990) Zapiski knjagini E.R. Dashkovoj. Reprintnoe vosproizvedenie. M.: Izd-vo «Nauka». $-528 \mathrm{~s}$.

3- Ivanova L.P. (2013) Afrika glazami N.S. Gumileva (lingvoimagologicheskij aspekt) // Uchenye zapiski Tavricheskogo nacional'nogo universiteta im. V.I. Vernadskogo. T 26 (65). № 1. Filologija. Social'naja kommunikacija. - Simferopol', - s. 471-477.

4- Ivanova L.P. (2014). Lingvoimagologija kak kraeugol'nyj kamen' teorii kommunikacii $i$ prakticheskie osnovy mezhkul'turnoj kommunikacii II Kommunikativnye issledovanija. Izd-vo «Omskijo universitet». № 1, s. 9-16.

5- Ivanova L.P. (2016). Jazykovaja lichnost' kn. E.R. Dashkovoj (lingvoimagologicheskij $i$ gendernyj aspekty) //Movna osobistist': lingvistika i lingvodidaktika (tekst) MON Ukraïni, Kï̈vs'kij nacional'nij lingvistichnij universitet. Cherkas'kij nacional'nij universitet im. B. Hmel'nic'kogo. Kiïv Cherkasi: Vid-vo Chabanenko Ju.A. s. 34-38. 
6- Ivanova L.P. (2016). Zhanrovye osnovanija lingvoimagologicheskogo analiza // Zhanry rechi. Mezhdunarodnyj nauchnyj zhurnal. Izd-vo Saratovskogo universiteta, № 1, s. 148-155.

7- Maslova V.A. (2001). Lingvokul'turologija: Ucheb. posobie dlja studentov vysshih uchebnyh zavedenij. M.: Izdatel'stkij centr «Akademija», - $208 \mathrm{~s}$.

8- Maslova V.A. (2008). Sovremennye napravlenija v lingvistike: uchebnoe posobie dlja studentov vysshih uchebnyh zavedenij / V.A. Maslova. - M.: Izdatel'skij centr «Akademija», - $274 \mathrm{~s}$.

9- Orehov V.V. (2008). Mif o Rossii vo francuzskoj literature pervoj poloviny XIX veka. - Simferopol': OAO «Simferopol'skaja gosudarstvennaja tipografija» (SGT), $200 \mathrm{~s}$.

10- Pushkin A.S. (1962). Sobranie sochinenij v 10-ti tomah. T. VI. Kritika i publicistika. Gos. izd-vo hudozhestvennoj literatury. - M., $-586 \mathrm{~s}$.

11- Solncev V.M. (1971). Jazyk kak sistemno-strukturnoe obrazovanie. - M., Glavnaja redakcija vostochnoj literatury izdatel'stva «Nauka». - $294 \mathrm{~s}$.

12- Fonvizin D.I. (1959). Sobranie sochinenij v 2 t., T. 2. GIHL, M-L., - 742 s.

\section{HOW TO CITE THIS ARTICLE}

Ivanova, L.(2019). Linguo-imagology as a New Integrating Direction of Linguistics. Issledovatel'skiy Zhurnal Russkogo Yazyka I Literatury, 13, 45-64.

DOI: $10.29252 /$ iarll. 13.45

URL: http://journaliarll.ir/index.php/iarll/article/view/44

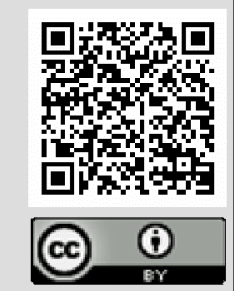


ايماكولوزى زبانشناختى به عنوان گرايش جديد در زبانشناسى

\author{
ليودميلا يتروونا ايوانورا'

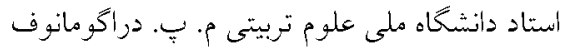 \\ كيف، أكراين.

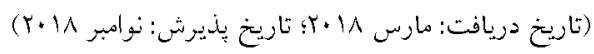

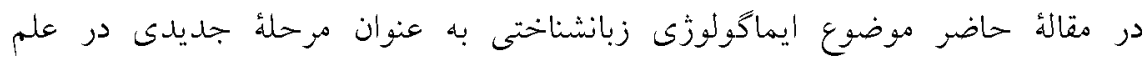

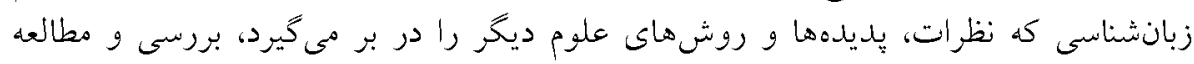

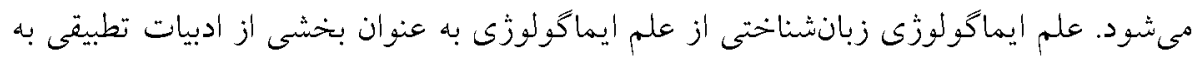

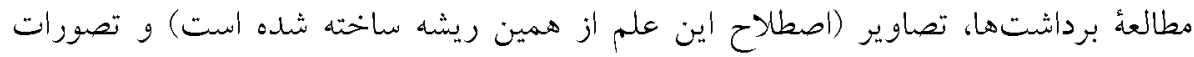

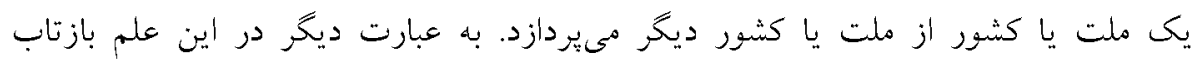

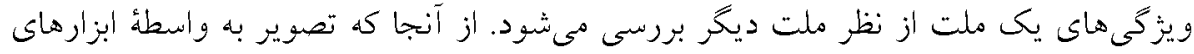

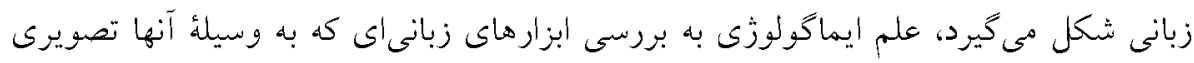

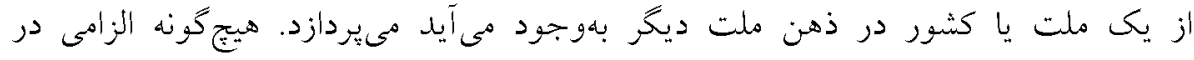

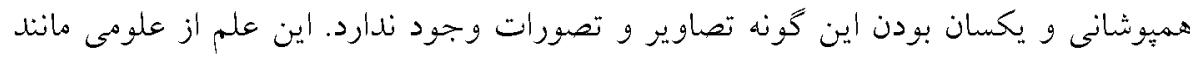

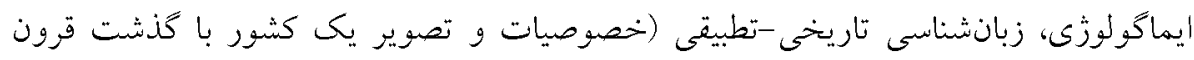

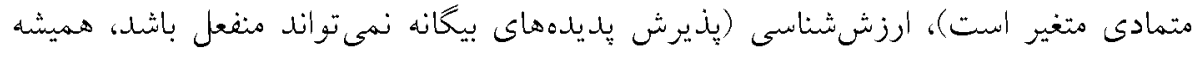

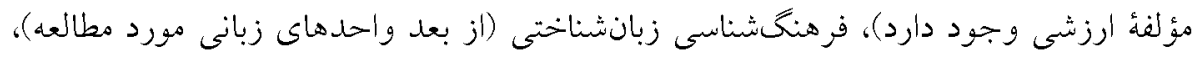

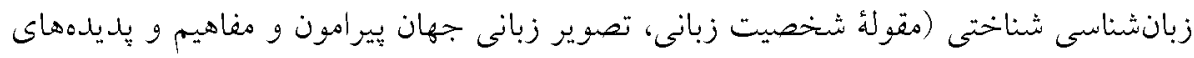

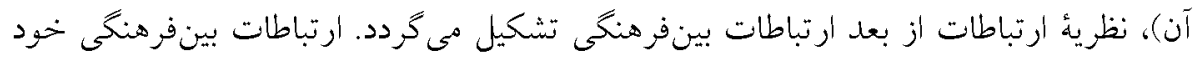

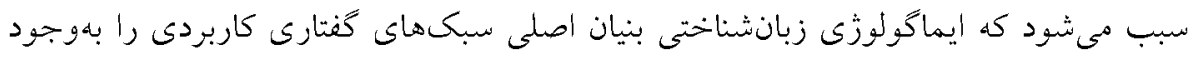

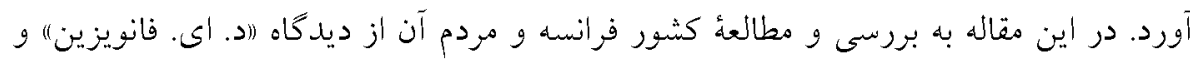

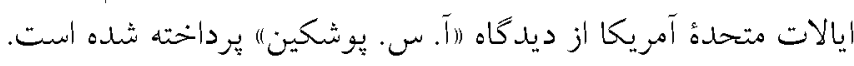

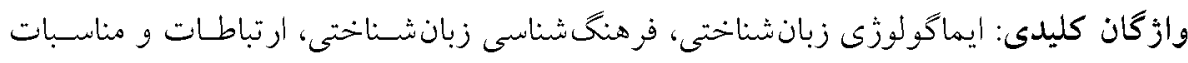

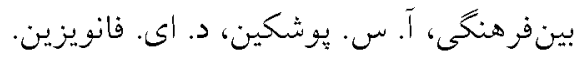

